ТЕОРИЯ И ИСТОРИЯ ГОСУДАРСТВА И ПРАВА

\author{
УДК 340.153 \\ DOI 10.17308/vsu.proc.law.2020.1/2396
}

\title{
О СУДЕБНОЙ СИСТЕМЕ НОВГОРОДСКОЙ РЕСПУБЛИКИ
}

\author{
М. Е. Омельяненко
}

Владивостокский государственный университет эконолики и сервиса

Поступила в редакцию 28 мая 2019 г.

\begin{abstract}
Аннотация: статья посвящена исследованию норл Новгородской судной гралоты, регулирующих судоустройство Новгородской республики в XV в. Рассмотрень виды судебньх учреждений, образованных в Новгородской республике, дана попьтка детализации их колпетениии, а также отражено участие населения в фборлировании и фбнкиионировании судов в Новгороде. Данное исследование проведено с использованием всеобщего диалектического метода познания, позволюющего рассматривать явления в их систелнол развитии, взаилосвязи и взаилозависилости. В основе работы лежит исторический подход к изучаельм явлениям, используются проблелно-хронологический, фборлально-юридический методь, а также общенаучные приемы познания (анализ, синтез, дедукиия, индукиия, сравнение и др.).

Ключевые слова: Новгородская судная гралота, участие населения в форлировании судебньх органов, участие населения в отправлении правосудия, вече, княжеский суд, суд налестника и посадника, суд тыссяикого, суд тиуна, суд одрина, бояре, житьи.
\end{abstract}

Abstract: the article is devoted to the study of the rules of the Novgorod judicial charter, regulating the judicial system of the Novgorod Republic in the 15th century. A feature of the emerging justice of Novgorod is the widespread involvement of the population in the administration of justice. This circumstance is due to a number of reasons related to the peculiarities of the formation of the Novgorod Republic by its territorial location, climatic conditions, as well as economic and political relations with other principalities and states. The article considers the types of judicial institutions formed in the Novgorod Republic and gives an attempt to detail their competence, as well as reflects the participation of the population in the formation and functioning of the courts in Novgorod.

This study was conducted using the universal dialectical method of cognition,

116 which allows us to consider phenomena in their systemic development, interconnection and interdependence. The work is based on a historical approach to the phenomena studied, using problem-chronological, formal-legal methods, as well as general scientific methods of cognition (analysis, synthesis, deduction, induction, comparison, etc.).

Key words: the Novgorod judicial Charter, participation in the formation of the judiciary, popular participation in the administration of justice, the chamber, the princely court, the Governor and mayor, the court of the captain, the court Chiune, the court Audrina, nobles, itii.

История Новгорода в сравнении с историей других городов Древней Руси более детально отражается в летописных источниках и археологи-

(C) Омельяненко M. E., 2020 


\section{Теория и история государства и права}

ческих исследованиях, поскольку Новгород в полной мере не испытал татаро-монгольского нашествия.

Новгород возник в результате слияния боярских поселков (патронимий ${ }^{1}$, обширных территорий Приильменья, и был полностью «обояренным» аристократическим городом ${ }^{2}$, с изначально сильным влиянием вече на управление делами Новгорода.

По аналогии с некоторыми регионами средневековой Западной Европы (Генуя, Венеция) в Новгороде сложился своеобразный республиканский (феодальный) строй ${ }^{3}$, отличный от остальных русских княжеств в период феодальной раздробленности Руси. Этому способствовал ряд причин, обусловленных территориальным расположением и климатическими условиями Новгорода, которые отличались от тех факторов, повлиявших на образование государств Южной Руси в Среднего Поднепровья, возникавших в районах с большей концентрацией сельского населения, занимавшегося земледелием. Новгородская республика располагалась на северных территориях Русского государства ${ }^{4}-$ на землях с низкой плодородностью, но богатых полезными ископаемыми (залежи железной руды, соляные месторождения), которые способствовали развитию ремесленничества - солеварению и обработке железа; лесные богатства - деревообработке и пушного промысла, а наличие многочисленных рек - жемчужному промыслу

Кроме того, торговый путь «из варяг в греки» проходил по территории Новгорода, что способствовало развитию производства и торговли и в конечном итоге вхождению Новгорода в Ганзейский торговый союз $(1391-1494 \text { гг. })^{6}$.

${ }^{1}$ Патрони́мия (греч. Patronymía - наименование по отцу, от patér - отец и ónyma - имя) - форма общественного устройства патриархально-родового строя. Представляет собой группу семей, образовавшихся в результате разрастания и сегментации одной патриархальной семейной общины, сохраняющих в той или иной мере и форме хозяйственное, общественное и идеологическое единство и носящих общее патронимическое наименование, образованное от собственного имени главы разделившейся семьи (см.: Косвен М. О. Семейная община и патронимия. М., 1963. С. 98).

${ }^{2}$ См.: Алешковский $M . X$. Социальные условия формирования территории 117 Новгорода в IX-XV вв. // Советская археология. 1974. № 3. С. 110.

${ }^{3}$ См.: Рыљбаков Б. А. Мир истории. Начальные века русской истории. М., 1987. URL: https://www.twirpx.com/file/1273152 (дата обращения: 01.04.2019).

${ }^{4}$ См.: Ключевский В. О. Курс русской истории : соч. : в 9 т. Т. 1 : Лекция XXIII. M., 2005. URL: http://rtunes.ru/content/ebooks/free_ebooks/vasily_klyuchevsky/ russian_history_full_course_of_lectures/russian_history_full_course_of_lectures. a4.pdf (дата обращения: 01.04.2019).

${ }^{5}$ См.: Подвигина Н. Л. Очерки социально-экономической и политической истории Новгорода Великого в XII-XIII вв. М., 1976. С. 50-52.

${ }^{6}$ См.: Лагунин И. И. Изборск и Ганза. Нибуров мир. 1391 г. // Вестник Псковского гос. ун-та. Серия: Социально-гуманитарные и психолого-педагогические науки. 2013. № 2. С. 33-39; Кулишер И. М. История русской торговли и промышленности. Челябинск, 2003. С. 52-53. 


\section{Вестник ВГУ. Серия: Право}

Означенные выше моменты и соседство с Ливонским орденом и Швецией, посягавшими на территорию Новгорода, не могли не повлиять на характер имевшихся в Новгороде общественных отношений, для регулирования которых уже было недостаточно положений Русской Правды.

Однако побудительной причиной создания Новгородской судной грамоты (далее - НСГ) ${ }^{7}$, по нашему мнению, являлся тот факт, что начиная со второй четверти XIV в. усиливается политическое влияние на Новгород со стороны Московского княжества и желание московских князей присоединить территорию Новгорода к своему княжеству. Именно поэтому НСГ можно оценивать, прежде всего, как акт, упорядочивающий взаимные отношения между управленческими структурами Новгорода и московских князей в условиях нараставшей со стороны Московского княжества экспансии. В пользу этого предположения свидетельствуют три аргумента: 1) московские князья с 1325 г. одновременно занимали стол в Новгороде (табл.); 2) до 1325 г. имели место перечисленные выше детерминанты

Т а б ли ц а

Княжение в Новгородской республике и Московском княжестве $X I V-X V$ вв. ${ }^{8}$

\begin{tabular}{|c|c|c|c|}
\hline \multicolumn{2}{|c|}{ Московское княжество } & \multicolumn{2}{|c|}{ Новгородская республика } \\
\hline $\begin{array}{c}\text { период } \\
\text { правления }\end{array}$ & князь & $\begin{array}{c}\text { период } \\
\text { правления }\end{array}$ & князь \\
\hline $1325-1341$ & Иван I Данилович Калита & $1328-1340$ & Иван I Данилович Калита \\
\hline $1341-1353$ & Семен Иванович Гордый & $1340-1353$ & Семен Иванович Гордый \\
\hline $1354-1359$ & Иван II Иванович Красный & $1353-1359$ & Иван II Иванович Красный \\
\hline $1359-1389$ & $\begin{array}{l}\text { Дмитрий Иванович Дон- } \\
\text { ской }\end{array}$ & $1363-1389$ & $\begin{array}{l}\text { Дмитрий Иванович Дон- } \\
\text { ской }\end{array}$ \\
\hline $1389-1425$ & Василий I Дмитриевич & $1389-1425$ & Василий I Дмитриевич \\
\hline $1425-1462$ & $\begin{array}{l}\text { Василий II Васильевич } \\
\text { Темный }\end{array}$ & $1425-1462$ & $\begin{array}{l}\text { Василий II Васильевич } \\
\text { Темный }\end{array}$ \\
\hline $1462-1506$ & $\begin{array}{l}\text { Иван III Васильевич Вели- } \\
\text { кий }\end{array}$ & $1462-1505$ & $\begin{array}{l}\text { Иван III Васильевич Вели- } \\
\text { кий }\end{array}$ \\
\hline
\end{tabular}

своеобразия Новгорода: развитие промыслов, торговли, включая внешнюю (известны факты сношений Новгорода с другими государствами еще в XI-XII вв. $\left.{ }^{9}\right)$ и пр., тем не менее самостоятельного нормативного правового акта новгородцами не принималось вплоть до 1456 г.; по мнению Л. В. Черепнина, этот акт создан в XIV в., что подтверждает высказанную нами гипотезу о первопричине появления НСГ - необходимости упоря-

${ }^{7}$ Новгородская судная грамота // Российское законодательство X-XX вв. : в 9 т. T. 1 : Законодательство Древней Руси. М., 1984. С. 300-320.

${ }^{8}$ Сведения приведены по: Главы Русского государства. Полный список князей, царей и президентов // Аналитическая газета. URL: https://www.anaga.ru/ tsari.htm (дата обращения: 03.04.2019).

${ }^{9}$ Памятники русского права. Вып. 2 : Памятники права фреодально-раздробленной Руси. XII-XV вв. / сост. А. А. Зимин ; под ред. С. В. Юшкова. М., 1953. C. 124-132. 


\section{Теория и история государства и права}

дочения отношений с московскими князьями ${ }^{10}$; 3 ) нормы НСГ в основном касаются организационных аспектов формирования судебных мест с соблюдением интересов Новгорода и Московского князя. Об этом же свидетельствует и то обстоятельство, что сохранившаяся редакция НСГ 1471 г. была переписана от имени Ивана III после заключения Коростынского мира, завершившего феодальную войну между Московским княжеством и Новгородом.

Нормативную основу НСГ составили княжеские уставы, грамоты и устоявшиеся положения из судебной практики и договоров со славянскими княжествами и иностранными государствами.

Регулирование только некоторых общественных отношений нормами НСГ обусловлено тем, что данный нормативно-правовой акт лишь дополнял положения Русской Правды, а не полностью ее замещал.

В указанной судной грамоте нашли свое отражение особенности организации власти Новгорода, в том числе и судебной, имеющей свои отличия, детерминированные перечисленными выше и рядом других причин.

Организация власти в Новгороде была дуалистичной. Часть власти принадлежала представительному органу - вече, а часть призывной власти - князю ${ }^{11}$.

Новгородское судоустройство имело достаточно сложную структуру и отличалось тем, что во всех судебных органах имелись представители населения. Помимо этого, все судебные органы можно разделить в соответствии с современной терминологией на суды общей и специальной компетенции (рис. 1).

К судам общей компетенции относились суды князя, вечевой, посадника и наместника, тиуна, а также суд одрина. $К$ специализированным порубежный, церковный (владычный), сместный, таможенный и проезжий суды.

Подробно разграничить компетенщию судов общей юрисдикции достаточно сложно. $К$ сожалению, в НСГ полномочия того или иного суда не отмечены. Эти сведения отсутствуют и в берестяных грамотах.

В силу ограниченности объема публикации в настоящей статье рассматривается система судов общей юрисдикции.

Княжеский суд в Новгороде осуществлялся князем с обязательным 119 участием посадника со стороны народного представительства (рис. 2).

${ }^{10} \mathrm{O}$ датировке НСГ см.: Мрочек-Дроздовский П. Н. Главнейшие памятники русского права эпохи местных законов // Юридический вестник. 1884. Т. 16, № 5/6. С. 119 ; Беляев И. Д. Лекции по истории русского законодательства / предисл. А. Д. Каплина; отв. ред. О. А. Платонов. М., 2011. С. 458 ; Черепнин Л. В. Русские феодальные архивы. М., 1948. Ч. 1. С. 226 ; и др.

11 Здесь и далее речь идет о Новгородском князе, в случае упоминания иных князей они именуются Тверской князь или великий князь Московский, в определенных случаях они также могли являться профессиональными участниками судопроизводства, особенно при усилении влияния Московского княжества и его вмешательстве в управление делами Новгорода. 


\section{Вестник ВГУ. Серия: Право}

\begin{tabular}{|c|c|}
\hline Судебная система Новгородской \\
республики в XII-XVI вв. \\
\hline Суды общей компетенции \\
\hline Княжеский суд \\
\hline Вучевой суд \\
\hline Суд тысяцкого \\
\hline Суд тиуна \\
\hline
\end{tabular}

Puc. 1. Система судоустройства Новгородской республики в XII-XVI вв.

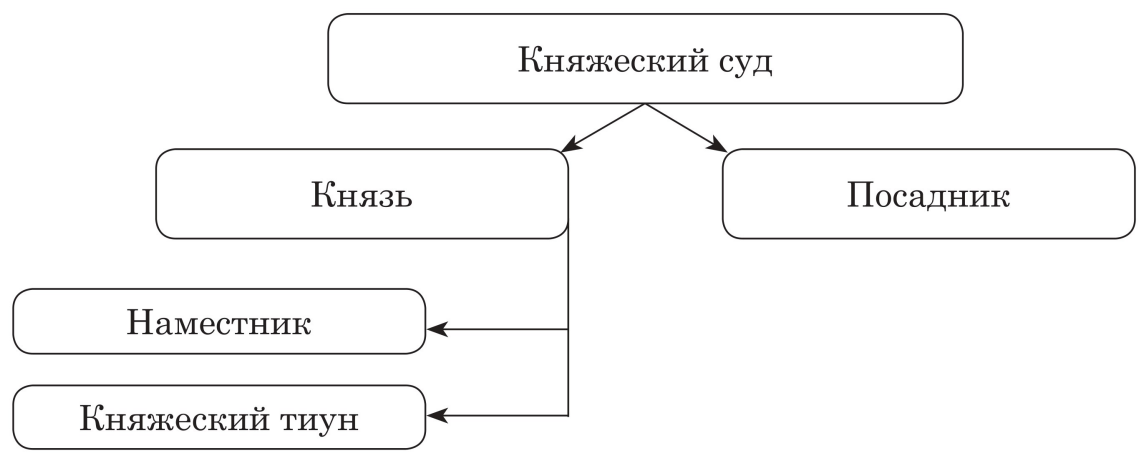

Puc. 2. Устройство княжеского суда в Новгородской республике XII-XVI вв.

В Новгороде князь отправлял свое правосудие лично или через своих наместников, тиунов ${ }^{12}$ (ст. 3 НСГ). Судебные полномочия князя ограничивались договором (рядом) ${ }^{13}$, заключаемым с Новгородом при вступлении на новгородский стол ${ }^{14}$. Князь не мог судить и решать важнейшие административные вопросы, в том числе и судебные, в отсутствие посадника ${ }^{15}:$ «...без посадника ти, княже, суда не судити, ни волостей раздавати, ни грамот ти даяти» ${ }^{16}$. В компетенцию князя и посадника входило

${ }^{12}$ См.: Куницын А. П. Историческое изображение древнего судопроизводства в России. СПб., 1843. С. 16-18.

${ }_{13}$ См.: Молотов В. В. Формирование русского средневекового права в IXXIV вв. M., 2003. С. 96.

${ }^{14}$ См.: Подвигина Н. Л. Указ. соч.

${ }^{15}$ См.: Юшков С. В. История государства и права России (IX-XIX вв.). Ростов н/Д., 2003. С. 454-455.

${ }^{16}$ Договорная грамота Новгорода с Тверским великим князем Ярославом Ярославичем (1270г.). URL: http://www.vostlit.info/Texts/Dokumenty/Russ/XIII/12601280/Gramoty_otn_Novgoroda_knjaz/1-20/3.htm (дата обращения: 10.05.2019). 


\section{Теория и история государства и права}

разрешение имущественных споров, что с развитием ремесленничества и торговли для Новгорода являлось достаточно актуальным.

Князь в Новгороде был лишен права владения имуществом, ему выделялся только княжеский домен и кормление на период его княжения. Такая особенность статуса князя представляется в его беспристрастности и незаинтересованности в исходе дела. А участие посадника в разрешении споров князем обеспечивало соблюдение традиций и обычаев Новгорода, о которых князь мог быть не осведомлен в силу того, что не являлся коренным новгородцем.

Князь имел право делегировать свои полномочия по отправлению правосудия. При назначении на низшие управленческие (судебные) должности, замещаемые не по вечевому выбору, а по княжескому назначению, князь должен был избирать людей из новгородского общества, а не из своей дружины ${ }^{17}$. Данное обстоятельство свидетельствует о прерогативе новгородского населения в исполнении судебных функций. Таким образом исключительное право князя вершить правосудие контролировалось новгородцами.

Вече принимало участие в отправлении правосудия через своих представителей (рис. 3).

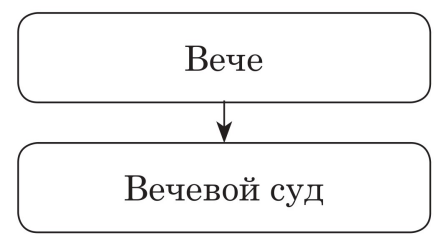

Puc. 3. Устройство вечевого суда в Новгородской республике XII-XVI вв.

Вопрос судебной компетенции веча является дискуссионным ${ }^{18}$. Судебные полномочия вече подтверждаются рядом летописных свидетельств ${ }^{19}$. Вечевому суду подлежала городская знать, а также дела, при разрешении которых затрагивались интересы всего Новгорода или по которым назначалось наказание в виде смертной казни. Можно предположить, что судебная компетенция веча имела экстраординарный характер ${ }^{20}$.

Спорным является вопрос о том, насколько вече отражало интересы всего населения Новгорода. По мнению В. Л. Янина, вся территория Новгорода состояла исключительно из боярских усадеб ${ }^{21}$, владельцы которых

${ }^{17}$ См.: Ключевский В. О. Указ. соч.

${ }^{18}$ См.: Сергеевич В. И. Древности русского права. Вече и князь. Советники князя. СПб., 1908. Т. 2. С. 102.

${ }^{19}$ См.: Полное собрание русских летописей, изданное по высочайшему повелению Археографической комиссии. T. 4. IV. V. Новгородские и псковские летописи. CПб., 1848. URL: https://www.prlib.ru/item/692540 (дата обращения: 05.05.2019).

${ }^{20}$ См.: Верещагина A. В. Становление и развитие уголовной юстиции России : дореволюционный период. Владивосток, 2009. С. 26-27.

${ }^{21}$ Янин В. Л. Таинственный XIV век // Знание - сила. 1969. № 7. С. 14. 


\section{Вестник ВГУ. Серия: Право}

и осуществляли политическую и судебную власть в городе ${ }^{22}$. Соответственно Новгородское вече, «объединяло лишь крупнейших фееддалов и было не народным собранием, а собранием класса, стоящего у власти» ${ }^{23}$, число участников которого составляло первоначально 300 человек (по 100 человек от каждого конца), а с образованием двух новых концов возросло до $500^{24}$. Свою гипотезу ученый обосновывает результатами археологических раскопок, в соответствии с которыми место собрания горожан (Ярославово дворище) было относительно небольшим, на нем могли одновременно собраться не более 300-500 человек, что соответствовало численности бояр, владевших городскими усадьбами ${ }^{25}$. Аналогичной позиции придерживается и А. М. Купрач, заявляя, что «вече предстает, на первый взгляд, весьма демократическим институтом, который решает наиболее важные государственные вопросы и даже походит на "народовластие». Но первое впечатление обманчиво, социальная неоднородность древнерусского общества, породила аристократический государственный строй ... уже начиная с XII в., знать фактически подчинила своей воле вечевые собрания» ${ }^{26}$. Б. Д. Греков оценивал вече как «орган непосредственной демократии, деятельностью руководили высшие слои новгородского общества. Свой довод он обосновывал тем, что новгородское вече являлось результатом определенного соотношения классовых сил, при котором феодальная знать, захватившая в свои руки власть и ограничившая в своих интересах власть князей, не была в силах уничтожить народное собрание, но была достаточно сильна, чтобы превратить его в орудие своих интересов» ${ }^{27}$. Подобной позиции придерживался и С. В. Юшков, подчеркивавший, что вече было органом власти «феодальных групп, а не широкой городской демократией» ${ }^{28}$.

${ }^{22}$ См.: Янин В. Л. Основные исторические итоги археологического изучения Новгорода // Новгородские археологические чтения : материалы науч. конф., посвященной 60-летию археологического изучения Новгорода и 90-летию со дня рождения А. В. Арциховского. (В. Новгород, 28 сентября - 2 октября 1992 г.) / под ред. В. Л. Янина и П. Г. Гайдукова. В. Новгород, 1994. С. 9-27.

${ }_{23}^{3}$ Янин В. Л. Проблемы социальной организации Новгородской республики // История СССР. 1970. № 1. С. 44, 50-51.

$122 \quad{ }^{24}$ Река Волхов делила Новгород на две стороны: правую - по восточному берегу и левую - по западному; первая называлась Торговой, потому что здесь находился главный городской рынок - торг; вторая носила название Софийской, на которой после принятия христианства был построен храм св. Софии. Кроме того, Новгород делился на пять концов: два конца располагались на Торговой стороне - Славянский и Плотницкий, и три на Софийской - Людин, Загородский и Неревский.

${ }^{25}$ См.: Янин В. Л. Социально-политическая структура Новгорода в свете археологических исследований // Новгородский исторический сборник. Л., 1982. Вып. 1 (11). С. 94.

${ }^{26}$ Купрач A. M. Вече - древняя и средневековая фрорма выборов и прямой демократии на Руси // Народный календарь. 2012. № 37. С. 7-9.

${ }^{27}$ Греков Б. Д. Киевская Русь. М., 1949. С. 364.

${ }^{28}$ Юшков С. В. Очерки по истории феодализма в Киевской Руси. М. ; Л., 1939. C. 196 . 


\section{Теория и история государства и права}

С указанной гипотезой не согласен В. Ф. Андреев, проанализировавший летописные и иные свидетельства и пришедший к выводу о том, что княжеский - «Ярославов двор» - располагался не к западу, а к югу и юго-востоку от Никольского собора ${ }^{29}$, где на обширной территории могли поместиться несколько тысяч человек. Это соответствует числу участников Новгородского вече, определенному А. В. Майоровым ${ }^{30}$.

Участие свободных горожан разного статуса на вече подтверждается летописными источниками, в статье Устюжского летописного свода под $1477 / 78$ г. повествуется о «брани» на вече между боярами и чернью ${ }^{31}$. Полагаем, что независимо от участия простолюдинов на вече правом решающего голоса обладала аристократия (бояре, житьи).

Исходя из вышеизложенного, представляется, что, несмотря на дискуссионность некоторых вопросов, в том числе и представительства классов и сословий на вечевом собрании населения в Новгородской республике, вечевое начало значительно преобладало над властью княжеской. Данный вывод основан на том, что в компетенцию веча, помимо указанных выше судебных полномочий, входило принятие новых законов, приглашение князя или его изгнание, избрание, решение вопроса о войне и мире и т. п. ${ }^{32}$

Как указано выше, отправлением правосудия в Новгороде занимались посадник и налестник (рис. 4).

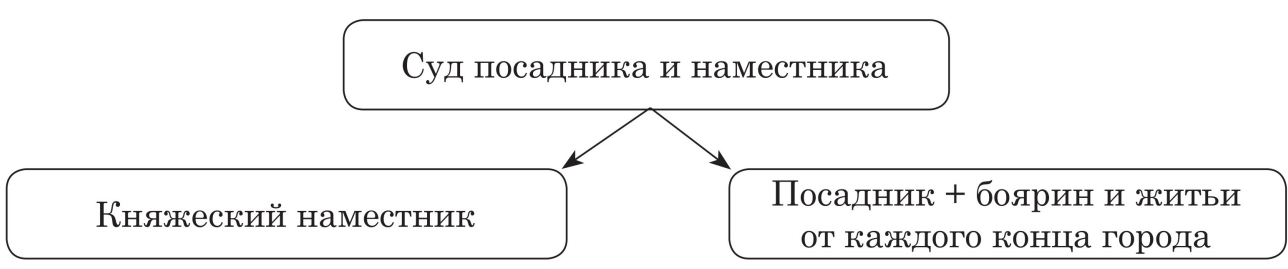

Puc. 4. Устройство суда посадника и наместника в Новгородской республике XII-XVI вв.

Издревле посадником на Руси называлось должностное лицо, избираемое на вече, в полномочия которого входило управление делами на определенной территории, в том числе и урегулирование споров. С установлением княжеской власти указанные фрункции стал исполнять

${ }^{29}$ См.: Андреев В. Ф. Княжеский двор в древнем Новгороде // Новгородский исторический сборник. Л., 1984. Вып. 2 (12). С. 119.

${ }^{30}$ См.: Майоров A. В. О составе участников древнерусского веча (по материалам Новгорода и других регионов Древней Руси) // Петербургские чтения - 96 : материалы Энциклопедической библиотеки «Санкт-Петербург - 2003». СПб., 1996. C. 326-329.

${ }^{31}$ Полное собрание русских летописей. Т. 37 : Устюжские и вологодские летописи XVI-XVIII вв. Л., 1982. С. 94.

${ }^{32}$ См.: Ключевский В. О. Указ. соч. 


\section{Вестник ВГУ. Серия: Право}

наместник, считавшийся ставленником князя ${ }^{33}$. Это свидетельствует о преемственности института посадничества и наместничества при переходе от родоплеменной (соседской) общины к феодализму и установлению княжеской власти.

В Новгороде посадник не трансформировался в институт наместника, как это произошло на остальной территории Русского государства, они существовали параллельно, взаимодействуя друг с другом. Об этом свидетельствует ст. 2 НСГ, где указано, что данные лица занимаются совместным отправлением правосудия.

Подсудность дел, относящихся к ведению посадника и княжеского наместника аналогична компетенции князя и посадника. Это обусловлено правом князя делегировать часть полномочий своим наместникам для выполнения судебных функций в свое отсутствие или на отдаленных территориях.

При отправлении правосудия посадником и наместником население Новгорода помимо посадника было представлено боярами и житьими, по двое с каждой стороны города. Житьими именовались зажиточные купцы-землевладельцы или купеческие старосты ${ }^{34}$, еще их называли «меньшие бояре» ${ }^{35}$. Подобный институт, по мнению А. П. Куницына, существовал и у германских племен, там указанные лица назывались ротниками, они привлекались тогда, когда против обвиняемого не доставало улик, и он не мог доказать свою невиновность, в таком случае спор передавался на разрешение ротников. Подобная аналогия встречается и у древних англосаксов, датчан, шведов и норвежцев. По законам этих народов истец назначал шесть человек присяжных, и столько же назначал ответчик ${ }^{36}$.

В случае отправления правосудия непосредственно самим князем участие бояр и житьих не предусматривалось. Данный фракт может свидетельствовать о том, что князь судил только высшие слои новгородского общества, т. е. самих бояр и житьих людей.

Точных сведений о разграничении компетенции князя и его наместника нет, но можно предположить, что разграничение компетенции происходило исходя из социального положения лица, подлежащего суду.

Помимо княжеского наместника и посадника, судебными функциями

124 обладал тысяикий, избираемый на вече из новгородских бояр (рис. 5).

Информация, имеющаяся в источниках, дает только общие сведения об этом судебном учреждении. Первоначально тысяцкий на Руси являлся военным руководителем десяти сотских, в связи с этим можно предположить, что указанное лицо обладало судебными полномочиями в военных

${ }^{33}$ См.: Коловская E. В. Проблемы синонимии в социальной терминологии «Истории государства российского» Н. М. Карамзина // Филологические науки. Вопросы теории и практики. 2008. № 1/2 (1). С. 41-43.

${ }^{34}$ См.: Лукин П. В. Категории населения Новгорода в опасной грамоте 1472 г. // Slověne. 2015. T. 4, № 1. C. 253-265.

35 Янин В. Л. Новгородские посадники. М., 2003. С. 129.

${ }^{36}$ См.: Куницьцн А. П. Указ. соч. С. 23. 


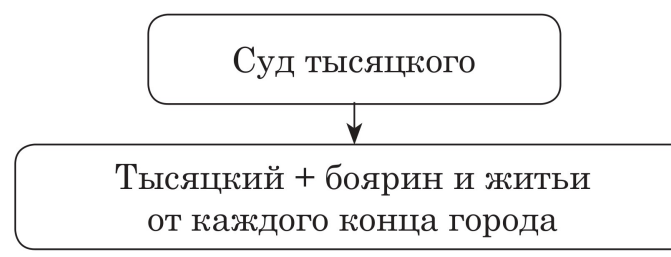

Puc. 5. Устройство суда тысяцкого в Новгородской республике XII-XVI вв.

походах. Указанный правовой институт отчасти сопоставим с отроком, упоминаемым в Русской Правде (ст. 7, 9, 16 Русской Правды по Троицкому и Карамзинскому спискам), который принимал участие в походах, сборе дани и при этом занимался отправлением правосудия в отношении княжеских дружинников, с той лишь разницей, что отрок являлся младшим дружинником князя, а тысяцкий - военачальником.

Вместе с тем тысяцкому были подсудны торговые споры; предполагаем, что это связано с тем, что он принимал участие в походах для заключения торговых соглашений.

При рассмотрении дел судом посадника, княжеского наместника или тысяцкого принимали участие представители Новгорода - по боярину и житьиму от каждой стороны города (ст. 5). Участие населения при отправлении правосудия указанных лиц подтверждается Никоновской летописью: «...Посаднику и тысяцкому судите свои суды, по русскому обычаю, по целованию, а на суд пошлите по два боярина и по два мужа житейска от каждой стороны» ${ }^{37}$.

Новгородская судная грамота (ст. 25) содержит упоминание об еще одной судебной инстанции - суда тиуна (рис. 6$)^{38}$.

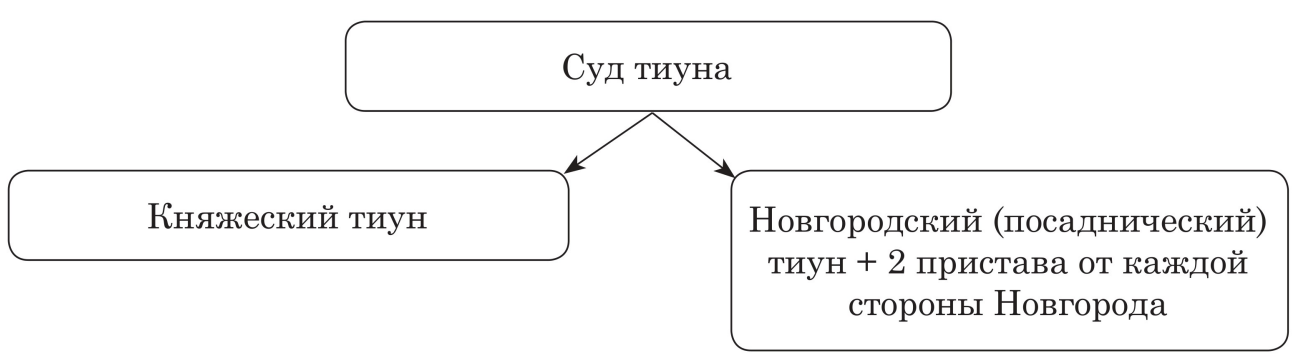

Puc. 6. Устройство суда тиуна в Новгородской республике XII-XVI вв.

Участвовать при разрешении спора судом тиуна мог как княжеский, так и новгородский (посаднический) тиун. Определить компетенцию

${ }^{37}$ Полное собрание русских летописей, изданное по высочайшему повелению Археографической комиссии. Т. 9 : VIII Летописный сборник, именуемый Патриаршей или Никоновской летописью. СПб., 1862. URL: https://www.runivers.ru/upload/iblock/1d0/Polnoe\%20sobranie\%20rus\%20letopisey\%209.pdf (дата обращения: 05.05.2019).

${ }^{38}$ См.: Агафонов С. Ю. Суды с народным представительством в России в X начале XX века : историко-правовое исследование : дис. ... канд. юрид. наук. Н. Новгород, 2011. С. 30-31. 


\section{Вестник ВГУ. Серия: Право}

каждого из этих составов суда не представляется возможным; предполагаем, что она определялась по территориальному или персональному критерию. Данное суждение подтверждается договорной грамотой Новгорода с тверским князем Михаилом Александровичем 1304-1305 гг. В грамоте устанавливается правило, в соответствии с которым княжеский и посадский тиуны должны были разрешать споры в зависимости от места их возникновения («А что ти, княже, пошло на Тържъку и на Волоце: тивунъ свои дьржати на своеи части, а новгородца на своеи части» $)^{39}$. Подобные положения мы находим и в более поздних грамотах. Например, в договорной грамоте Новгорода с литовским князем Казимиром 1440-1447 гг. определяется, в каких волостях административно-судебную власть осуществляет княжеский тиун, а в каких - новгородский, при этом указывается, что в некоторых областях княжеский и новгородский тиуны осуществляют совместный суд («напол»): «А на Молвятичохъ взяти ми, князю великому, два рубля, а тиуну рубль за петровщину; на Куньску възяти мне, князю великому, рубль, а тиуну полтина ... а на Лукахъ нашь тиунъ, а вашь другии: судъ имъ наполъ; а торопечкому тиуну по новгородскои волости не судити, ни ржевьскому...»" .

В приведенных выше договорах ("докончаниях») идет речь о разрешении конфликта между жителями Новгорода и соседних княжеств, поэтому княжеский и посадский тиун вместе должны были разрешать спор.

В НСГ усматриваются нормы, разделявшие суды на инстанции (первую и апелляционную в современном их понимании).

Высшей судебной инстанцией в Новгороде являлся суд одрина или суд докладчиков (рис. 7), который пересматривал дела по уже принятым решениям.

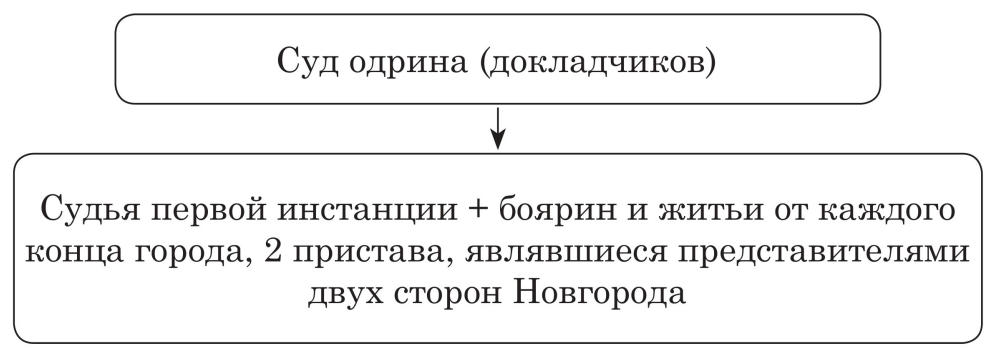

Рuc. 7. Устройство суда одрина (суда докладчиков) в Новгородской республике XII-XVI вв.

Свое название суд одрина получил благодаря помещению, в котором проводились заседания - одринной (владычной) комнате, расположенной в доме новгородского архиепископа. Согласно положений ст. 26 НСГ

${ }^{39}$ Грамота Новгорода тверскому великому князю Михаилу Ярославичу с условиями договора 1304-1305 гг. // Грамоты Великого Новгорода и Пскова / под ред. С. Н. Валка. М. ; Л., 1949. С. 15-16.

40 Договорная грамота литовского великого князя Казимира с Великим Новгородом о мире 1440-1447 гг. // Грамоты Великого Новгорода и Пскова / под ред. С. Н. Валка. М. ; Л., 1949. С. 115-116. 


\section{Теория и история государства и права}

он состоял из судей первой инстанции, двух приставов от каждой стороны Новгорода и по одному боярину и житьему от каждого конца, которых называли докладчиками по делу, отсюда следует второе название данного суда. Можно предполагать, что выбором докладчиков занималось вече, поскольку оно принимало активное участие в формировании судебных органов. Докладчики наблюдали за правильностью проведения судебного разбирательства и утверждали принятое решение. В их отсутствие запрещалось вершить суд в Новгороде. Они собирались для рассмотрения дела три раза в неделю: понедельник, среду и пятницу, а за свою неявку несли ответственность в виде штрафа, бояре в размере 2 рублей, а житьи - 1 рубля (ст. 26), что являлось достаточно существенной суммой. Например, 1 новгородский рубль равнялся гривне серебра (204 г) или 40 золотников $\left(4,27 \times 40\right.$ г) ${ }^{41}$.

Помимо пересмотра судебных решений, суд одрина рассматривал также земельные споры, в том случае если суд первой инстанции не вынес своего решения в течение двух месяцев (ст. 29).

Аналогичную организацию судебных мест можно встретить у сербов, которые привлекали к участию в судебном процессе «поротци» и у чехов «помощники» и «очистицы» ${ }^{2}$.

Некоторые ученые (А. П. Куницын), сопоставляя положения ст. 25 и $26 \mathrm{HC}^{43}$, утверждают, что суд докладчиков возглавлял княжеский тиун, тем самым суд одрина тождествен суду тиуна. Данный вывод А. П. Куницын основывает на положениях договора 471 г., заключенного между Новгородом и польским королем Казимиром: "А тиуну своему судить в Одрине с Новгородскими приставами». Однако, по нашему мнению, это свидетельствует лишь о том, что тиун мог возглавлять суд докладчиков, наряду с другими судьями, рассматриввшими дела по первой инстанции. Иными словами, происходит отождествление тиуна с высшим должностным лицом, которым он не являлся ${ }^{44}$.

Таким образом, особое влияние на фрормирование судебной системы оказали две причины: притязание Московского княжества на новгородский престол и географическое и социально-экономическое положение Новгородской республики. Первое обусловило формирование судов на паритетных началах между Новгородом и Московией, которые делегиро-

${ }^{41}$ См.: Чудовский Д. Н. «Новгородки». Критический разбор первых двух выпусков Русской допетровской нумизматики гр. Ив. Ив. Толстого. Киев, 1887. С. 9.

${ }^{42}$ См.: Костомаров Н. И. Русская республика (Севернорусские народоправства во времена удельно-вечевого уклада. История Новгорода, Пскова и Вятки). Исторические монографии и исследования. (Серия «Актуальная история России»). М. ; Смоленск, 1994. URL: http://www.e-reading.mobi/bookreader.php/149391/ Kostomarov_-_Russkaya_respublika_\%28Severnorusskie_narodopravstva_vo_ vremena_udel\%27no-vechevogo_uklada._Istor--yatki\%29..html (дата обращения: 15.05.2019).

${ }^{43}$ См.: Куницыц А. П. Указ. соч. С. 33.

${ }^{44}$ См.: Владилирский-Буданов $М$. Ф. Хрестоматия по истории русского права. Киев, 1885. Вып. 1. С. 201. 


\section{Вестник ВГУ. Серия: Право}

вали в них своих представителей. Второе повлияло на систему судебных учреждений, которая являлась полисистемной и инстанционной. При этом нормы, позволявшие четко разграничить компетенцию отдельных звеньев судебной системы отсутствовали. Можно предположить, что имелось два основных критерия разграничения подсудности: персональная (социальное положение тяжущихся лиц) и предметная (существо рассматриваемого спора).

Владивостокский государственньй университет эконолики и сервиса

Олельяненко M. E., аспирант, старший преподаватель кафбедры уголовно-правовых дисииплин

E-mail: mariyaomelyanenko@yandex.ru
Vladivostok State University of Economics and Service

Omelyanenko M. E., Post-graduate Student, Senior Lecturer of the Criminal Law Disciplines Department

E-mail: mariyaomelyanenko@yandex.ru 